\section{Self-Assembly of Gold(I) Compounds with (Aza-15-crown-5)dithiocarbamate and 2-Mercapto-4-methyl-5-thiazoleacetic Acid}

\author{
Biing-Chiau Tzeng, ${ }^{*},+$ Wei-Hsin Liu ${ }^{\dagger}{ }^{J}$ u-H siou Liao, ${ }^{\dagger}$ Gene-Hsiang Lee, ${ }^{\ddagger}$ and \\ Shie-Ming Peng ${ }^{\ddagger}$
}

Department of Chemistry and Biochemistry, National Chung Cheng University, 160 San-Hsin, Min-Hsiung, Chia-Yi, Taiwan 621, and Department of Chemistry, National Taiwan University, Taipei, Taiwan

Received October 29, 2003; Revised Manuscript Recei ved J anuary 29, 2004

\begin{abstract}
Treatment of $\mathrm{AuCl}\left(\mathrm{SMe}_{2}\right)$ with equimolar sodium (aza-15-crown-5)dithiocarbamate $\left(\mathrm{O}_{4} \mathrm{NCS}_{2}\right)$ or 2-mercapto-4-methyl-5-thiazoleacetic acid ( $\mathrm{HSSCOOH})$ in the presence of $\mathrm{NaOMe}$ affords a dinuclear complex, [Au$\left.\left(\mathrm{O}_{4} \mathrm{NCS}_{2}\right)\right]_{2} \mathbf{1}$, and a tetranuclear complex, $[\mathrm{Au}(\mathrm{SSCOOH})]_{4} \mathbf{2}$, respectively. $\mathbf{1}$ features a dinuclear structure containing two azacrown ether rings, and there is a short intramol ecular gold(I ) .. gold (I) distance of $2.7820(5) \AA$. I mportantly, $\mathbf{2}$ crystallizes in two forms: 2.4THF and 2.4DMF, where the solvent molecules are hydrogen-bonded to the carboxylic acid moiety of SSCOOH. 2.4THF and 2.4DMF are tetranuclear complexes featuring an interesting double-clipped structure built from both thiazole rings and carboxylic acid moieties. The four gold(I) centers in $\mathbf{2}$ form a puckersquared channel with four equivalent gold(I) $\cdots$ gold(I) distances of 3.0478(4) $\AA$ for 2.4THF and 3.0423(4) $\AA$ for 2. $4 \mathrm{DMF}$, respectively, and this one-dimensional channel structure may be rationalized by $\pi \cdots \pi$ interactions and/or weak intermolecular Au...S interactions of $3.800 \AA$ for $\mathbf{2 . 4 T H F}$ or $3.986 \AA$ for $\mathbf{2} \cdot 4 \mathrm{DMF}$, respectively. Interestingly, with the same synthetic strategy $\mathbf{1}$ and $\mathbf{2}$ are formed with different nuclearities. This dramatic different structural motif between $\mathbf{1}$ and $\mathbf{2}$ may be ascribed to crystal packing of azacrown ether rings in part. At room temperature, $\mathbf{2}$ shows low-energy dual emissions with maxima at 585 and $720 \mathrm{~nm}$, whereas it shows only a strong emission with a maximum at $585 \mathrm{~nm}$ at $77 \mathrm{~K}$. This interesting luminescence property is suggested to be closely related to aurophilic interactions.
\end{abstract}

\section{Introduction}

The propensity for closed-shell $d^{10}$ gold(I) centers to form weakly bonding interactions, leading to a large variety of supramolecular gold(I ) compounds with novel structural and intriguing spectroscopic properties, has recently been an interesting and common feature in gold chemistry. ${ }^{1-10}$ These interactions are typically identified by means of X-ray diffraction studies in all cases in which gold(I) -..gold(I) distances are less than or close to the sum of the van der Waals radii (3.32 A). ${ }^{11}$ Mingos and co-workers ${ }^{7 a}$ used the reaction of $\left[\mathrm{Au}\left(\mathrm{NH}_{3}\right)_{2}\right] \mathrm{BF}{ }_{4}$ with $\mathrm{t}-\mathrm{BuC} \equiv \mathrm{CH}$ to synthesize the first gold(I )-containing catenane, $[\mathrm{Au}(\mathrm{t}-\mathrm{BuC} \equiv \mathrm{C})]_{6}$, which was shown by $X$-ray diffraction to have close intra- and inter-ring gold(I) $\cdots$ gold(I) contacts in a range between 3.2 and $3.5 \AA$. Puddephatt et al. ${ }^{5 a}$ have recently further elaborated the useful application of aurophilicity in the construction of supramolecular gold(I)-containing rings and catenanes by a self-assembly process.

The presence of aurophilic contacts may be recognized not only from short gold(I) …gold(I) distances and novel structural features, but also intriguing electronic absorption and luminescence properties. It is becoming clear that the gold $(I) \cdots$ gold $(I)$ bonding interactions are responsible for the relevant transitions, and luminescence has thus become an important diagnostic tool for aurophilicity. ${ }^{12}$ Recently, a spectacular experiment carried out by Balch et al.3a has demonstrated that

\footnotetext{
* To whom correspondence should be addressed.

† National Chung Cheng University.

₹ National Taiwan University.
}

luminescence of gold(I) complexes can be triggered by the solvation of the donor-free solid substrate either from the vapor phase or by dissolving the material in a solvent. In the meantime, a remarkable example of the strong solvent dependence of the luminescence of a gold(I) compound in solution has also been observed by Che and co-workers. ${ }^{10 \mathrm{~d}}$ Moreover, an unusual chromic luminescence behavior linked to a structural change in the solid-state induced by exposure to the vapor phase of volatile organic compounds (VOCs) was al so observed by E isenberg and co-workers. ${ }^{13}$ This "luminescent switch" for the detection of VOCs using gold(I) dimers, following the pioneering work by Mann and co-workers ${ }^{14}$ on absorption and emission spectra of vapochromic platinum(II) and palladium(II) compounds, suggests that such gold(I) compounds hold great potential for analyti$\mathrm{cal} /$ sensor applications.

Zanazzi el al ${ }^{15}$ in 1980 reported the first air-stable dithiocarboxylic acid derivative of $\mathrm{gold}(\mathrm{I}),\left[\mathrm{Au}\left(\mathrm{CH}_{3}-\right.\right.$ CSS) $]_{4}$. In the tetranuclear structure, the four gold(I) centers are at the vertices of a rhomboid. The four bridging ligands are alternately above and below the plane of four gold(I) centers, where the molecule is almost symmetric and has an approximate $D_{2}$ symmetry. Another interesting example was reported by J ones et al. ${ }^{16}$ in 1999, i.e., [Au(etu-H) $]_{4}$ (etu = imidazolidine-2thione), in which the tetranuclear complex is further linked into chains by intermolecular gold(I) ... gold(I) contacts. Thus, the interesting family of tetranuclear complexes $[\mathrm{AuL}]_{4}(\mathrm{~L}=$ anionic ligands) seem still rare. However, molecular materials composed of discrete metal clusters are useful model systems for understand- 
Table 1. Crystallographic Data for 1, 2.4THF, and 2.4DMF

\begin{tabular}{|c|c|c|c|}
\hline & 1 & 2.4THF & $\mathbf{2 \cdot 4 D M F}$ \\
\hline $\begin{array}{l}\text { emp form } \\
\text { form wt }\end{array}$ & $\begin{array}{l}\mathrm{C}_{22} \mathrm{H}_{40} \mathrm{Au}_{2} \mathrm{~N}_{2} \mathrm{O}_{8} \mathrm{~S}_{4} \\
982.73\end{array}$ & $\begin{array}{l}\mathrm{C}_{20} \mathrm{H}_{28} \mathrm{Au}_{2} \mathrm{~N}_{2} \mathrm{O}_{6} \mathrm{~S}_{4} \\
914.62\end{array}$ & $\begin{array}{l}\mathrm{C}_{18} \mathrm{H}_{26} \mathrm{Au}_{2} \mathrm{~N}_{4} \mathrm{O}_{6} \mathrm{~S}_{4} \\
916.60\end{array}$ \\
\hline cryst sys & triclinic & tetragonal & tetragonal \\
\hline space group & $\mathrm{P} \overline{1}$ & $\mathrm{I}_{1} / \mathrm{a}$ & $\mathrm{I}_{1} / \mathrm{a}$ \\
\hline a $(\AA)$ & $8.1657(2)$ & $14.2833(6)$ & $14.3972(9)$ \\
\hline$b(\AA)$ & $8.6329(2)$ & $14.2833(6)$ & $14.3972(9)$ \\
\hline$c(\AA)$ & $11.2093(3)$ & $25.1256(11)$ & $26.008(3)$ \\
\hline$\alpha\left(^{\circ}\right)$ & $75.0558(10)$ & 90 & 90 \\
\hline$\beta\left(^{\circ}\right)$ & $85.0939(11)$ & 90 & 90 \\
\hline$\gamma\left({ }^{\circ}\right)$ & $88.4651(15)$ & 90 & 90 \\
\hline $\mathrm{V}\left(\AA^{3}\right)$ & $760.65(3)$ & $5125.9(4)$ & $5390.9(8)$ \\
\hline$\rho_{\text {calc }}\left(\mathrm{g} \mathrm{cm}^{-3}\right)$ & 2.145 & 2.370 & 2.259 \\
\hline & 1 & 8 & 8 \\
\hline$\mu(\mathrm{Mo}-\mathrm{K} \alpha)\left(\mathrm{cm}^{-1}\right)$ & 99.53 & 118.00 & 112.23 \\
\hline$F(000)$ & 472 & 3456 & 3456 \\
\hline $\mathrm{T}(\mathrm{K})$ & $150(1)$ & 150(1) & $273(2)$ \\
\hline $\begin{array}{l}\text { obsd reflns } \\
\qquad\left(\mathrm{F}_{\mathrm{o}} \geq 2 \sigma \mathrm{F}_{\mathrm{o}}\right)\end{array}$ & 3501 & 2950 & 2112 \\
\hline $\begin{array}{l}\text { refined } \\
\text { parameters }\end{array}$ & 173 & 132 & 137 \\
\hline $\mathrm{R}^{\mathrm{a}}$ & 0.0427 & 0.0319 & 0.0360 \\
\hline $\mathrm{R}_{\mathrm{w}}^{\mathrm{b}}$ & 0.1013 & 0.0759 & 0.0833 \\
\hline
\end{tabular}

ing surface chemistry and catalysis, but the synthesis of such materials is usually serendipitous. To date, gold(I) thiolates are important substrates rel evant to quite a number of applications from surface technology to drug design ${ }^{2 f}$ and virtually all of the classical and modern drugs based on gold(I) compounds for arthritis and rheumatism have been gol d(I)-sulfur compounds. ${ }^{17-19}$ In this context, we report here studies on self-assembly of gold(I) compounds with (aza-15-crown-5)dithiocarbamate and 2-mercapto-4-methyl-5-thiazol eacetic acid leading to the formation of dinuclear and tetranuclear complexes, respectively, in which the latter not only features a novel structural motif, but also shows interesting photoluminescence.

\section{Experimental Section}

General Information. All reactions were performed under a nitrogen atmosphere and solvents for syntheses (analytical grade) were used without further purification. NMR: Bruker DPX $400 \mathrm{MHz} N M R$; deuterated solvents with the usual standards. 2-Mercapto-4-methyl-5-thiazol eacetic acid (HSS$\mathrm{COOH}$ ) is commercially available, and sodium (aza-15-crown5)dithiocarbamate $\left(\mathrm{NaO}_{4} \mathrm{NCS}_{2}\right)$ was prepared by literature methods. ${ }^{20}$

Synthesis. $\left[\mathrm{Au}\left(\mathrm{O}_{4} \mathrm{NCS}\right)_{2}\right]_{2}$ 1: The reaction of $\mathrm{NaO}_{4} \mathrm{NCS}_{2}$ (318 mg) with AuCl(SMe $)$ (295 mg) in $\mathrm{CH}_{2} \mathrm{Cl}_{2} / \mathrm{MeOH}(1: 1,50$ $\mathrm{mL}$ ) at room temperature for $4 \mathrm{~h}$ gave a pale yellow precipitate. The precipitate was filtered off in a vacuum, and $\mathbf{1}$ was obtained as a pale yellow solid in a $88 \%$ yield. Single crystals of $\mathbf{1}$ were grown by ether diffusion into a $\mathrm{CH}_{2} \mathrm{Cl}_{2} / \mathrm{MeOH}$ solution of $1^{1}{ }^{1} \mathrm{H}$ NMR (DMSO-d $\mathrm{d}_{6}, 25^{\circ} \mathrm{C}$ ): $\delta 3.699[\mathrm{~m}, 12 \mathrm{H}, 6$ $-\mathrm{CH}_{2}$ ], $3.926\left[\mathrm{t}, 4 \mathrm{H}, \mathrm{J} \mathrm{нн} 8.4 \mathrm{~Hz}, 2-\mathrm{NCH}_{2} \mathrm{CH}_{2}\right.$ ], 4.071 [t, $4 \mathrm{H}$, J нн $8.7 \mathrm{~Hz}, 2-\mathrm{NCH}_{2}$ ]. Anal. Calcd (\%) for $\mathrm{C}_{22} \mathrm{H}_{40} \mathrm{Au}_{2} \mathrm{~N}_{2} \mathrm{O}_{8} \mathrm{~S}_{4}$ : C, 26.89; H, 4.10; N, 2.85. Found (\%): C, 26.86; H, 3.85; N, 3.01.

$[\mathrm{Au}(\mathrm{SSCOOH})]_{4}$ 2: The reaction of $\mathrm{NaSSCOOH}[211 \mathrm{mg}$, obtained from $\mathrm{HSSCOOH}(189 \mathrm{mg})$ and $\mathrm{NaOMe}(56 \mathrm{mg})$ in $\mathrm{MeOH}(25 \mathrm{~mL})]$ with AuCl$\left(\mathrm{SMe}_{2}\right)(295 \mathrm{mg})$ in $\mathrm{CH}_{2} \mathrm{Cl}_{2} / \mathrm{MeOH}$ $(1: 1,50 \mathrm{~mL})$ at room temperature for $4 \mathrm{~h}$ gave a pale-yellow precipitate. The precipitate was filtered off in a vacuum and 2 was obtained as a pale yellow solid in a 95\% yield. Single crystals of 2.4THF were grown by slow evaporation of a THF solution and 2.4DMF grown from ether diffusion into a DMF solution. Both solvated solvents are easily lost leading to crystal cracking. ${ }^{1} \mathrm{H}$ NMR (DMSO- $\left.\mathrm{d}_{6}, 25{ }^{\circ} \mathrm{C}\right) \delta 2.50[\mathrm{~s}, 3 \mathrm{H}$,
$\left.-\mathrm{CH}_{3}\right], 3.68\left[\mathrm{~s}, 2 \mathrm{H},-\mathrm{CH}_{2}-\right], 9.68[\mathrm{~s}, 1 \mathrm{H},-\mathrm{COOH}]$. Anal. Calcd (\%) for $\mathrm{C}_{24} \mathrm{H}_{24} \mathrm{Au}_{4} \mathrm{~N}_{4} \mathrm{O}_{8} \mathrm{~S}_{8}$ : C, 18.71; $\mathrm{H}, 1.57 ; \mathrm{N}, 3.64$. Found (\%): C, 18.86; H, 1.75; N, 3.31.

Physical Measurements and Instrumentation. Steadystate emission spectra were measured on a SPEX Fluorolog-2 spectrophotometer, and emission lifetimes were measured with a Quanta Ray DCR-3 Nd:YAG laser (pulse output 355 nm, $8 n s)$. The decay signal was recorded by a R928 PMT (Hamamatsu), connected to a Tektronix 2430 digital oscilloscope.

X-ray Crystallography. Suitable crystals were mounted on a glass capillary. Data collection was carried out on a Bruker SMART CCD diffractometer with Mo radiation (0.71073 $\AA$ ) at $293 \mathrm{~K}$ for $2 \cdot 4 \mathrm{DMF}$ and $150 \mathrm{~K}$ for $\mathbf{1}$ and $2 \cdot 4 \mathrm{THF}$. A preliminary orientation matrix and unit cell parameters were determined from three runs of 15 frames each, each frame corresponding to $0.3^{\circ} \mathrm{scan}$ in $15 \mathrm{~s}$, followed by spot integration and least-squares refinement. Data were measured using an $\omega$ scan of $0.3^{\circ}$ per frame for $20 \mathrm{~s}$ until a complete hemisphere had been collected. Cell parameters were retrieved using SMART ${ }^{21}$ software and refined with SAINT ${ }^{22}$ on all observed reflections. Data reduction was performed with the SAINT software and corrected for Lorentz and polarization effects. Absorption corrections were applied with the program SAD$A B S .{ }^{23}$ The structure was solved by direct methods with the SHELX $93^{24}$ program and refined by full-matrix least-squares methods on $\mathrm{F}^{2}$ with SHEXLTL-PC V 5.03.24 All non-hydrogen atomic positions were located in difference $F$ ourier maps and refined anisotropically. The hydrogen atoms were placed in their geometrically generated positions. Detailed data collection and refinement of the complexes are summarized in Table 1.

\section{Results and Discussion}

Complexes $\mathbf{1}$ and $\mathbf{2}$ were prepared by treating $\mathrm{AuCl}$ $\left(\mathrm{SMe}_{2}\right)$ with equimolar $\mathrm{NaO}_{4} \mathrm{NCS}_{2}$ and $\mathrm{NaSSCOOH}$, respectively (Scheme 1). Interestingly, with the same synthetic strategy complexes $\mathbf{1}$ and $\mathbf{2}$ are formed with high yield of 88 and $95 \%$, respectively, but with different nuclearity. Single crystals of $\mathbf{1}$ were grown by ether diffusion into a $\mathrm{CH}_{2} \mathrm{Cl}_{2} / \mathrm{MeOH}$ solution of $\mathbf{1}$. Slow evaporation of a THF solution and ether diffusion of a DMF solution of $\mathbf{2}$ gave pale-yellow crystals of 2.4THF or $\mathbf{2 . 4 D M F}$, respectively. While dimeric complex $\mathbf{1}$ is nonemissive, the tetrameric complex $\mathbf{2}$ shows interesting solid-state photol uminescence. 


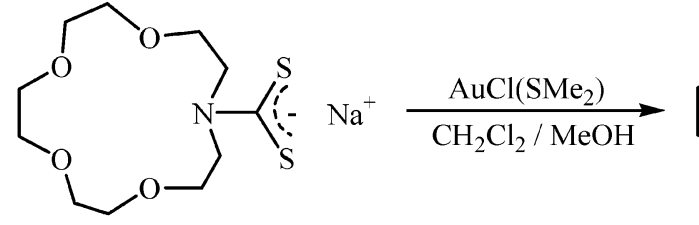
$\mathrm{NaO}_{4} \mathrm{NCS}_{2}$

\section{Scheme 1}<smiles>C1COCCOCCN(C2=[SH][Al]3SC(N4CCOCCOCCOCC4)=[SH][Al](S2)S3)CCOCCO1</smiles>

1<smiles>Cc1nc([N+](=O)[O-])sc1CC(=O)O</smiles>

$\mathrm{NaSSCOOH}$
Description of Crystal Structure. As shown in Figure la, 1 features an interesting dinuclear structure containing two azacrown ether rings, and there is a short intramolecular gold (I )...gold(I) distance of 2.7820(5) $\AA$. This short gold $(I) \cdots$ gol d (I) distance is remarkable when compared to the sum of the van der Waals radii of $3.32 \AA, 11$ but it is not uncommon for this class of compounds. ${ }^{4,13}$ Indeed, the value of 2.7820(5) $\AA$ in $\mathbf{1}$ agrees well with those values of 2.7690(7), 2.7916(12), and $2.7563(3) \AA$ in $\left[\mathrm{Au}\left(\mathrm{S}_{2} \mathrm{CN}\left(\mathrm{C}_{5} \mathrm{H}_{11}\right)_{2}\right)_{2}\right]^{13}$ with different solvates and other dinuclear gold(I) dithiocarbamates. ${ }^{4 b}$ Unlike the linear-chain complex of $\left[\mathrm{Au}\left(\mathrm{S}_{2} \mathrm{CN}\left(\mathrm{C}_{5} \mathrm{H}_{11}\right)_{2}\right)_{2}\right],{ }^{13}$ the close intermolecular gold $(\mathrm{I}) \cdots$ gold $(\mathrm{I})$ contact is absent in $\mathbf{1}$, and this is most likely ascribed to the bulky azacrown ether rings in the crystal lattice. Notably, the gold $(I) \cdots$ gold $(I)$ distance is ca. $0.32 \AA$ shorter than the value of $3.10 \AA$ for the intramolecular S...S distance of the dithiocarbamate, and this may be recognized as an indication of aurophilic attractions. A weak nonclassical hydrogen-bonding interaction $\left[\mathrm{C}\left(11^{\prime}\right)-\mathrm{H}\left(11 \mathrm{~B}^{\prime}\right) \cdots \mathrm{O}(4)\right.$ : $\mathrm{C}\left(11^{\prime}\right)-\mathrm{H}\left(11 \mathrm{~B}^{\prime}\right) 0.990 \AA, \mathrm{H}\left(11 \mathrm{~B}^{\prime}\right) \cdots \mathrm{O}(4) 2.560 \AA, \mathrm{C}\left(11^{\prime}\right)$.
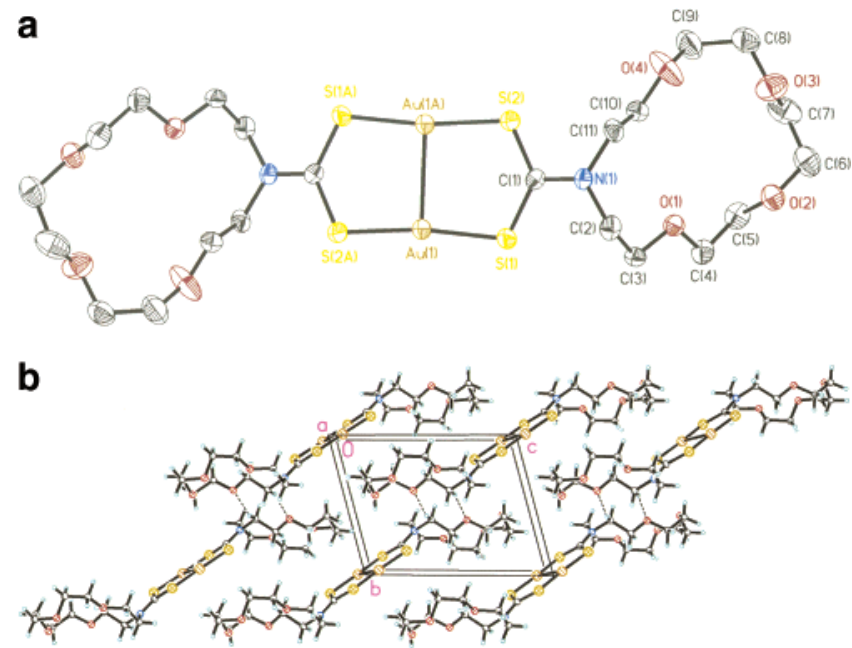

Figure 1. (a) Molecular structure of 1. ORTEP diagram shows $50 \%$ probability ellipsoids. Selected bond lengths $(\AA)$ and angles $\left({ }^{\circ}\right)$ : $\mathrm{Au}(1)-\mathrm{S}(1) 2.277(2), \mathrm{Au}(1)-\mathrm{S}(2 \mathrm{~A}) 2.273(2)$, $\mathrm{Au}(1) \cdots \mathrm{Au}(1 \mathrm{~A})$ 2.7820(5); $\mathrm{S}(2 \mathrm{~A})-\mathrm{Au}(1)-\mathrm{S}(1)$ 171.92(7). (b) The molecular packing of $\mathbf{1}$ with nonclassical hydrogen bonding data for $\mathrm{C}\left(11^{\prime}\right)-\mathrm{H}\left(11 \mathrm{~B}^{\prime}\right) \cdots \mathrm{O}(4)$ : $\mathrm{C}\left(11^{\prime}\right)-\mathrm{H}\left(11 \mathrm{~B}^{\prime}\right) 0.990$ $\AA, H\left(11 B^{\prime}\right) \cdots O(4) 2.560 \AA, C\left(11^{\prime}\right) \cdots O(4) 3.490 \AA ; C\left(11^{\prime}\right)-$ $\mathrm{H}\left(11 \mathrm{~B}^{\prime}\right) \cdots \mathrm{O}(4) 163.1^{\circ}$.
..O(4) $\left.3.490 \AA ; \mathrm{C}\left(11^{\prime}\right)-\mathrm{H}\left(11 \mathrm{~B}^{\prime}\right) \cdots \mathrm{O}(4) 163.1^{\circ}\right]$ is also observed in the solid state as shown in Figure $1 \mathrm{~b}$. The values of $\mathrm{Au}(1)-\mathrm{S}(1)[2.277(2) \AA]$ and $\mathrm{Au}(1)-\mathrm{S}(2 \mathrm{~A})$ $[2.273(2) \AA]$ fall in a normal range. ${ }^{4 b, 13}$

2 crystallizes in two forms: 2.4THF and 2.4DMF, which are almost isomorphous. The molecular structure and packing of 2.4THF as a representative example are shown in Figure 2. The molecular structure of $\mathbf{2}$ contains a 16-membered ring comprising the gold(I) centers, similar to structures reported by Zanazzi et al. ${ }^{15}$ and J ones et al., ${ }^{16}$ which features a tetrameric gold(I) complex with an interesting double-clipped structure built from both thiazole rings and carboxylic acid moieties. The four gold(I) centers form a puckered square with a pseudo symmetry of $\mathrm{S}_{4}$. The four equivalent gold(I) $\cdots$ gold(I) distances are 3.0478(4) $\AA$ for 2.4THF and 3.0423(4) $\AA$ for 2.4DMF, respectively, which are comparable to the average values of $3.01 \AA$ in $\left[\mathrm{Au}\left(\mathrm{CH}_{3} \mathrm{CSS}\right)\right]_{4}{ }^{15}$ and of $2.973(1) \AA$ in $[\mathrm{Au}(\text { etu-H })]_{4},{ }^{16}$ and significantly shorter than the value of 3.301(5) $\AA$ in $[\mathrm{AuCl} \text { (pip) }]_{4}$ (pip $=$ piperidine) $)^{25}$ with four gold(I) centers arranged in a square connected by intermolecular gold $(I) \cdots$ gold $(I)$ interactions. The transannular gold(I) ...gold(I) distance is $4.135 \AA$, significantly longer than the value of $3.29 \AA$ in $\left[\mathrm{Au}\left(\mathrm{CH}_{3} \mathrm{CSS}\right)\right]_{4}{ }^{15}$ Two slipped thiazole rings show the shortest distances of $3.48 \AA$ for 2.4THF and $3.42 \AA$ for 2.4DMF, respectively, between the $\mathrm{C}(\mathrm{N})$ and $\mathrm{C}(\mathrm{N})$ atoms and an almost parallel arrangement, and it is indicative of the possible existence of $\pi \cdots \pi$ interactions. Thus, the pucker-squared arrangement for four gold(I) centers may be explained by trying to maximize the $\pi \cdots \pi$ interactions for thiazole rings in the solid state. The four THF and DMF solvent molecules are strongly hydrogen-bonded to each SS$\mathrm{COOH}$ moiety between the oxygen atoms of THF or DMF and carboxylic acid moieties $[\mathrm{O}(2)-\mathrm{H}(2 \mathrm{~A}) \cdots \mathrm{O}(3)$ : $\mathrm{O}(2)-\mathrm{H}(2 \mathrm{~A}) 0.778 \AA, \mathrm{H}(2 \mathrm{~A}) \cdots \mathrm{O}(3) 1.905 \AA, \mathrm{O}(2) \cdots \mathrm{O}(3)$ $2.674 \AA$; $\mathrm{O}(2)-\mathrm{H}(2 \mathrm{~A}) \cdots \mathrm{O}(3) 159.0^{\circ}$ for $2 \cdot 4 \mathrm{THF}$ and $\mathrm{O}(2)-\mathrm{H}(2 \mathrm{~A}) \cdots \mathrm{O}(3): \mathrm{O}(2)-\mathrm{H}(2 \mathrm{~A}) 0.820 \AA, \mathrm{H}(2 \mathrm{~A}) \cdots \mathrm{O}(3)$ $1.810 \AA, \mathrm{O}(2) \cdots \mathrm{O}(3) 2.620 \AA ; \mathrm{O}(2)-\mathrm{H}(2 \mathrm{~A}) \cdots \mathrm{O}(3) 167.2^{\circ}$ for 2.4DMF] instead of the complementary hydrogen bonding between the carboxylic acid moieties originally expected. Because of the poor solubility, we failed to grow suitable single crystals without any solvate from aprotic solvents or other poor hydrogen-bonding donor solvents. However, the molecular packing of $2 \cdot 4 \mathrm{THF}$ or 
a

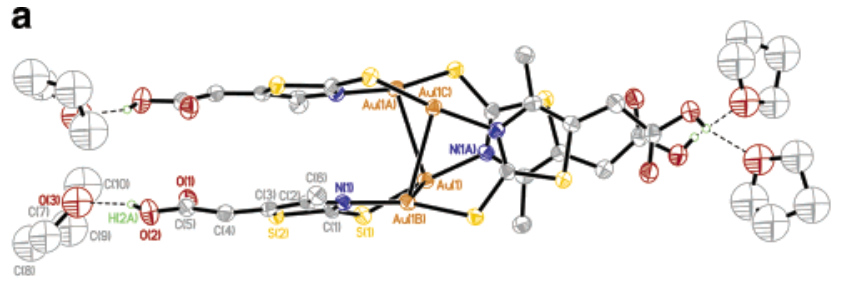

b

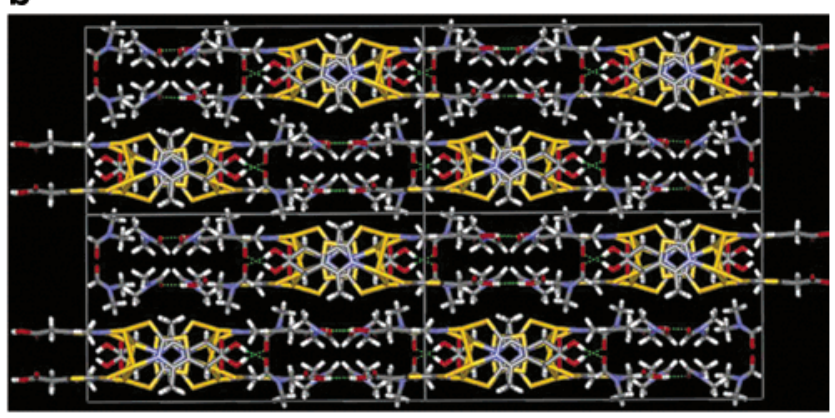

c

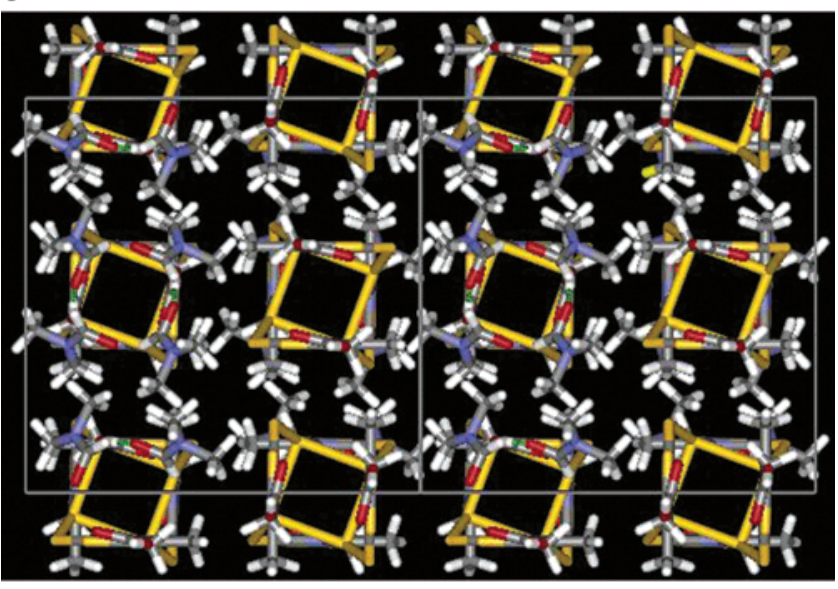

Figure 2. (a) Molecular structure of 2.4THF. ORTEP diagram shows $50 \%$ probability ellipsoids. Selected bond lengths $(\AA)$ and angles $\left({ }^{\circ}\right)$ : $\mathrm{Au}(1)-\mathrm{S}(1) 2.255(2), \mathrm{Au}(1)-\mathrm{N}(1 \mathrm{~A})$ 2.059(5), $\mathrm{Au}(1) \cdots \mathrm{Au}(1 \mathrm{~A})$ 3.0478(4), $\mathrm{Au}(1) \cdots \mathrm{Au}(1 \mathrm{~B}) 3.0478(4) ; \mathrm{N}(1 \mathrm{~A})-$ $\mathrm{Au}(1)-\mathrm{S}(1)$ 167.55(15). Hydrogen bonding data for $\mathrm{O}(2)-$ $\mathrm{H}(2 \mathrm{~A}) \cdots \mathrm{O}(3): \mathrm{O}(2)-\mathrm{H}(2 \mathrm{~A}) 0.778 \AA, \mathrm{H}(2 \mathrm{~A}) \cdots \mathrm{O}(3) 1.905 \AA$, $\mathrm{O}(2) \cdots \mathrm{O}(3) 2.674 \AA$; $\mathrm{O}(2)-\mathrm{H}(2 \mathrm{~A}) \cdots \mathrm{O}$ (3) $159.0^{\circ}$. (b) The molecular packing of 2.4THF featuring an interesting double-clipped structure with solvated THF molecules. (c) The one-dimensional channel structure is formed when viewing from the $c$ axis, where the dotted lines represent weak intermolecular Au...S interactions of $3.800 \AA$ for $\mathbf{2} \cdot 4$ THF (or $3.986 \AA$ for 2.4DMF). For clarity, the solvates are omitted.

2.4DMF still features an interesting one-dimensional channel structure with the pucker-squared dimension of $3.0478(4)$ or $3.0423(4) \AA$, respectively, as shown in Figure 2c. This one-dimensional channel structure may be due to $\pi \cdots \pi$ interactions and/or weak intermolecular Au...S interactions of $3.800 \AA$ for 2.4 THF or $3.986 \AA$ for 2.4DMF, respectively. The values of $\mathrm{Au}(1)-\mathrm{S}(1)$ $[2.256(2) \AA]$ and $A u(1)-N(1 A)$ [2.052(5) $\AA]$ also fall in a normal range. ${ }^{15,16}$ While the tetranuclear complexes of copper(I) or silver(I) are not uncommon, ${ }^{26}$ the related gold(I) analogues are still rare.15,16

Solid-State E mission Spectra. 2 (without solvates) show interesting solid-state photoluminescence, whereas $\mathbf{1}$ is nonemissive. Figure 3 shows the solid-state emissi on spectra of $\mathbf{2}$ measured at room temperature and at

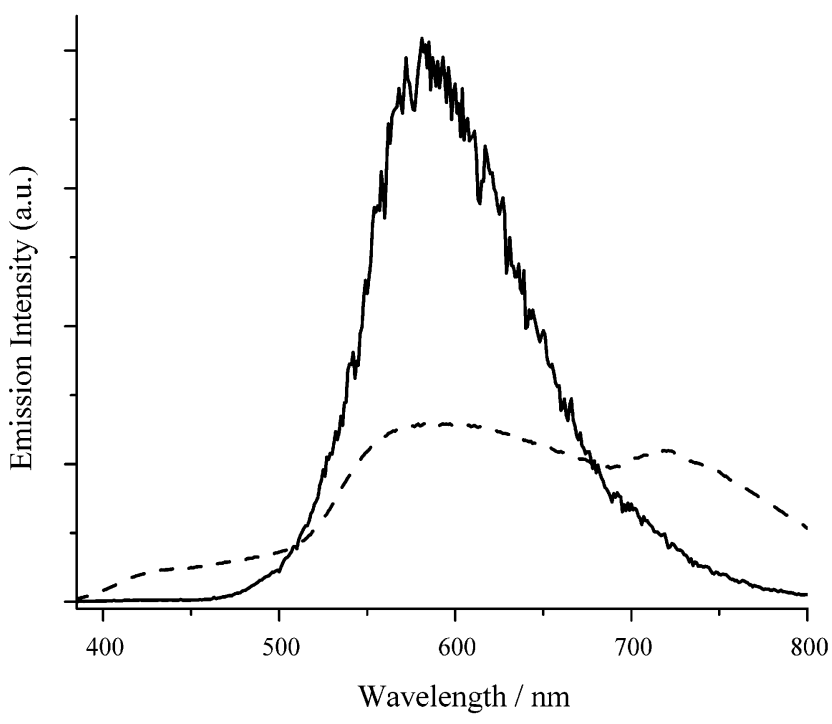

Figure 3. The solid-state emission spectra of $\mathbf{2}$ measured at room temperature (dash line) and at $77 \mathrm{~K}$ (solid line). Excitation at $355 \mathrm{~nm}$.

$77 \mathrm{~K}$. At room temperature, 2 shows low-energy dual emissions with maxima at 585 and $720 \mathrm{~nm}$. Upon cooling to $77 \mathrm{~K}, \mathbf{2}$ shows only a strong emission with a maximum at $585 \mathrm{~nm}$. The emissions at $585 \mathrm{~nm}$ are most likely due to a sulfur-to-metal charge-transfer (LMCT, $\mathrm{S} \rightarrow \mathrm{Au}$ ) transition modified by gold(I )...gold(I) interactions. The emission at $720 \mathrm{~nm}$ coming from a metalcentered $(5 d / 6 s \rightarrow 6 p)$ transition is anticipated because of the presence of multiple gold(I) $\cdots$ gold(I) interactions or a gold(I) cluster effect. Similar emission properties have been reported for the [(TPA)AuX] (X = Cl, Br, I; TPA $=$ 1,3,5-triaza-7-phosphaadamantane) ${ }^{27}$ and [N4P4$\left.(\mathrm{AuX})_{4}\right](\mathrm{X}=\mathrm{Cl}, \mathrm{Br}, \mathrm{I}$; N $4 \mathrm{P} 4=$ 1,4,8,11-tetra(diphenylp h o s p h i n o m e t h y l ) - 1, 4, 8, 11 tetraazacycl otetradecane) ${ }^{10 \mathrm{~b}}$ systems reported by Fackler et al. and Che et al., respectively. In these compounds, the low-energy emissions at 580-674 nm for [(TPA)$\mathrm{AuX}]^{27}$ and at $600-700 \mathrm{~nm}$ for $\left[\mathrm{N} 4 \mathrm{P} 4(\mathrm{AuX})_{4}\right]^{10 \mathrm{~b}}$ could come from metal-centered (5d/6s $\rightarrow 6 p)$ transitions, whereas the high-energy ones at 450-491 nm for $[(T P A) A u X]^{27}$ and at $530 \mathrm{~nm}$ for $\left[\mathrm{N} 4 \mathrm{P} 4(\mathrm{AuX})_{4}\right]^{10 \mathrm{~b}}$ are most likely due to metal-to-ligand charge-transfer $(\mathrm{MLCT}, \mathrm{Au} \rightarrow \mathrm{P})$ transitions. The emission at $720 \mathrm{~nm}$ for $\mathbf{2}$ is comparable to those at 580-674 and 600-700 $\mathrm{nm}$, and thus they are expected to have a similar emission origin due to a metal-centered $(5 d / 6 s \rightarrow 6 p)$ transition. However, the emission at $585 \mathrm{~nm}$ is quite red-shifted to those at 530 and $450-491 \mathrm{~nm}$, and this is because the sulfur-to-metal charge-transfer (LMCT, $\mathrm{S} \rightarrow \mathrm{Au}$ ) transition normally has a lower energy compared to those of metal-to-ligand charge-transfer $(\mathrm{MLCT}, \mathrm{Au} \rightarrow \mathrm{P})$ transitions. 28,29

\section{Conclusion}

Self-assembly of (aza-15-crown-5)dithiocarbamate or 2-mercapto-4-methyl-5-thiazol eacetic acid in the presence of $\mathrm{NaOM}$ e with gold(I ) centers leads to the formation of dinuclear and tetranuclear gold(I) complexes, respectively. 1 features a dinuclear structure containing two azacrown ether rings, and there is a short intramolecular gold(I )...gold(I) distance of 2.7820(5) A. Impor- 
tantly, 2 crystallizes in two forms: 2.4THF and 2.4DMF, where the solvent molecules are hydrogen bonded to the carboxylic acid moiety of SSCOOH. 2.4THF and 2.4DMF are tetranuclear complexes featuring an interesting double-clipped structure built from both thiazole rings and carboxylic acid moieties. The four gold(I) centers in $\mathbf{2}$ form a pucker-squared channel with four equivalent gold(I) $\cdots$ gold(I) distances of 3.0478(4) $\AA$ for 2.4THF and 3.0423(4) $\AA$ for 2.4DMF, respectively, and this one-dimensional channel structure may be rationalized by $\pi \cdots \pi$ interactions and/or weak intermolecular Au $\cdots$ S interactions of $3.800 \AA$ for $2.4 T H F$ or $3.986 \AA$ for 2.4DM F, respectively. Interestingly, with the same synthetic strategy $\mathbf{1}$ and $\mathbf{2}$ are formed with different nuclearities. This dramatic different structural motif between $\mathbf{1}$ and $\mathbf{2}$ may be ascribed to crystal packing of azacrown ether rings in part. At room temperature, $\mathbf{2}$ shows low-energy dual emissions with maxima at 585 and $720 \mathrm{~nm}$, whereas it shows only a strong emission with a maximum at $585 \mathrm{~nm}$ at $77 \mathrm{~K}$. This interesting luminescence property is suggested to be closely related to aurophilic interactions.

Acknowledgment. We thank the National Science Council and National Chung Cheng University of the Republic of China for financial support (NSC 90-2113M-194-028 and 91-2113-M-194-019).

Supporting Information Available: ORTEP (J PG) and CIF files of 2.4DMF, whose crystal structure is almost isomorphous with that of 2.4THF, although both contain different solvates. This material is available free of charge via the Internet at http://pubs.acs.org.

\section{References}

(1) (a) Pyykkö, P. Chem. Rev. 1997, 97, 597. (b) Pyykkö, P.; Zhao, Y. Angew. Chem., Int. Ed. Engl. 1995, 34, 1894. (c) Pyykkö, P.; Li, J .; Runeberg, N. Chem. Phys. Lett. 1994, 218, 133. (d) Pyykkö, P.; Zhao, Y. Chem. Phys. Lett. 1991, 177, 103. (e) Rösch, N.; Görling, A.; Ellis, D. E.; Schmidbaur, H. Angew. Chem., Int. Ed. Engl. 1989, 28, 1357. (f) Burdett, J K.; Eisenstein, O.; Schweizer, W. B. I norg. Chem. 1994, 33, 3261.

(2) (a) Schmidbaur, H. Gold Bull. 1990, 23, 11. (b) Schmidbaur, H.; Scherbaum, F.; Huber, B.; Müller, G. Angew. Chem., Int. Ed. Engl. 1988, 27, 419. (c) Schmidbaur, H. Chem. Soc. Rev. 1995, 24, 391. (d) Schmidbaur, H. Interdiscipl. Sci. Rev. 1992, 17, 213. (e) Schmidbaur, H. Gold Bull. 2000, 33, 1. (f) Gold: Progress in Chemistry, Biochemistry and Technology; Schmidbaur, H., Ed.; J. Wiley \& Sons: Chichester, 1999.

(3) (a) Vickery, J . C.; Olmstead, M. M.; Fung, E. Y.; Balch, A. L. Angew. Chem., Int. Ed. Engl. 1997, 36, 1179. (b) Vickery, J. C.; Balch, A. L. Inorg. Chem. 1997, 36, 5978. (c) Calcar, P. M. V.; Olmstead, M. M.; Balch, A. L. Inorg. Chem. 1997, 36, 5231. (d) Calcar, P. M. V.; Olmstead, M. M.; Balch, A. L. J . Chem. Soc., Chem. Commun. 1995, 1773.

(4) (a) Fackler, J . P., J r. Polyhedron 1997, 16, 1. (b) Fackler, J . P., J r. Inorg. Chem. 2002, 41, 6959.

(5) (a) Puddephatt, R. J . Coord. Chem. Rev. 2001, 216-217, 313. (b) Puddephatt, R. J . Chem. Commun. 1998, 1055. (c) Puddephatt, R. J. The Chemistry of Gold; Elsevier: Amsterdam, 1978.

(6) (a) Contel, M.; Garrido, J .; Gimeno, M. C.; J ones, P. G.; Laguna, A.; Laguna, M. Organometallics 1996, 15, 4939. (b) Gimeno, M. C.; Laguna, A. Chem. Rev. 1997, 97, 511.

(7) (a) Mingos, D. M. P.; Yau, J .; Menzer, S.; Williams, D. J . Angew. Chem., Int. Ed. Engl. 1995, 34, 1894. (b) Mingos, D. M. P. J . Chem. Soc., Dalton Trans. 1996, 561.

(8) (a) J ones, P. G.; Ahrens, B. New J . Chem. 1998, 104. (b) Chem. Ber./Recueil 1997, 130, 1813. (c) Vicente, J .; Chicote, M. T.; Abrisqueta, M. D.; Guerrero, R.; J ones, P. G. Angew. Chem., Int. Ed. Engl. 1997, 36, 1203.
(9) (a) Yam, V. W.-W.; Lo, K. K.-W. Chem. Soc. Rev. 1999, 28 , 323. (b) Yam, V. W.-W.; Cheng, C.-C. E. Angew. Chem., Int. Ed. Engl. 2000, 39, 4240. (c) Yam, V. W.-W.; Cheng, C.-C. E. Gold Bull. 2001, 34, 20.

(10) (a) Tzeng, B.-C.; Lo, W.-C.; Che, C.-M.; Peng, S.-M. Chem. Commun. 1996, 181. (b) Tzeng, B.-C.; Cheung, K.-K.; Che, C.-M. Chem. Commun. 1996, 1681. (c) Tzeng, B.-C.; Che, C.-M.; Peng, S.-M. J . Chem. Soc., Dalton Trans. 1996, 1769; 22. (d) Tzeng, B.-C.; Chan, C.-K.; Cheung, K.-K.; Che, C.M.; Peng, S.-M. Chem. Commun. 1997, 135. (e) Tzeng, B.C.; Che, C.-M.; Peng, S.-M. Chem. Commun. 1997, 1771.

(11) Bondi, A. J . Phys. Chem. 1964, 68, 441.

(12) (a) Che, C.-M.; K wong, H.-L.; Yam, V. W.-W.; Cho, K.-C. J . Chem. Soc., Chem. Comm. 1989, 885. (b) King, C.; Wang, J.-C.; Khan, M. N. I.; Fackler, J . P., J r. Inorg. Chem. 1989 28, 2145. (c) Gade, L. H. Angew. Chem., I nt. Ed. Engl. 1997, 36, 1171. (d) Fu, W.-F.; Chan, K.-C.; Miskowski, V. M.; Che, C.-M. Angew. Chem., Int. Ed. 1999, 38, 2783.

(13) Mansour, M. A.; Connick, W. B.; Lachicotte, R. J .; Gysling, H. J .; Eisenberg, R. J . Am. Chem. Soc. 1998, 120, 1329.

(14) Exstrom, C. L.; Sowa, J . R., J r.; Daws, C. A.; J anzen, D.; Moore, G. A.; Stewart, F. F.; Mann, K. R. Chem. Mater. 1995, 7, 15.

(15) Piovesana, O.; P. Zanazzi, F.; Angew. Chem., Int. Ed. Engl. 1980, 19, 561.

(16) J ones, P. G.; Friedrichs, S. Chem. Commun. 1999, 1365.

(17) (a) Shaw, C. F.; Coffer, M. T.; Klingbeil, J .; Mirabelli, C. K. J . Am. Chem. Soc. 1988, 110, 729. (b) Coffer, M. T.; Shaw, C. F.; Eidsness, M. K.; Watkins, J. W.; Elder, R. C. Inorg. Chem. 1986, 25, 333. (c) I sab, A. A.; Sadler, P. J . J . Chem. Soc., Dalton Trans. 1982, 135.

(18) Rapson, W. S.; Groenewald, T. In Gold Usage; Academic Press: London, 1978.

(19) Bain, C. D.; Whitesides, G. M. Angew. Chem., Int. Ed. Engl. 1989, 28, 506.

(20) Granell, J .; Green, M. L. H.; Lowe, V. J .; Marder, S. R.; Mountford, P.; Saunders, G. C.; Walker, N. M. J . Chem. Soc., Dalton Trans. 1990, 605.

(21) SMART V 4.043 Software for the CCD Detector System; Siemens Analytical Instruments Division, Madison, WI, 1995.

(22) SAINT V 4.035 Software for the CCD Detector System; Siemens Analytical Instruments Division, Madison, WI, 1995.

(23) Sheldrick, G. M. SHELXL-93, Program for the Refinement of Crystal Structures; University of Gottingen: Gottingen, Germany, 1993.

(24) SHELXTL 5.03 (PC Version), Program Library for Structure Solution and Molecular Graphics; Siemens Analytical Instruments Division, Madison, WI, 1995.

(25) Guy, J . J .; J ones, P. G.; Mays, M. J .; Sheldrick, G. M. J . Chem. Soc., Dalton Trans. 1977, 8.

(26) (a) Hope, H.; Power, P. P. Inorg. Chem. 1984, 23, 936. (b) Berry, M.; Clegg, W.; Garner, C. D.; Hiller, I. H. Inorg. Chem. 1982, 21, 1342. (c) Koten, G. v.; Noltes, J. G. J. Organomet. Chem. 1975, 84, 129. (d) Rodesiler, P. F.; Amma, E. L. J . Chem. Soc., Chem. Commun. 1974, 599. (e) S. Lawton, L.; Rohrbaugh, W.J .; Kokotailo, G. T. Inorg. Chem. 1972, 11, 612. (f) O'Connor, J . E.; J anusonis, G. A.; Corey, E. R. Chem. Commun. 1968, 445. (g) Fackler, J. P.; López, C. A. J r.; Staples, R. J .; Wang, S.; Winpenny, R. E. P.; Lattimer, R. P. J . Chem. Soc., Chem. Commun. 1992, 146.

(27) (a) Assefa, Z.; McBurnett, B. G.; Staples, R. J .; Fackler, J . P.; Assmann, B. J r.; Angermaier, K.; Schmidbaur, H. Inorg. Chem. 1995, 34, 75. (b) Assefa, Z.; McBurnett, B. G.; Staples, R. J .; Fackler, J . P., J r. Inorg. Chem. 1995, 34, 4965.

(28) (a) Narayanaswamy, R.; Young, M. A.; Parkhurst, E.; Ouellette, M.; Kerr, M. E.; Ho, D. M.; Elder, R. C.; Bruce, A. E.; Bruce, M. R. M. Inorg. Chem. 1993, 32, 2506. (b) J ones, W. B.; Yuan, J .; Narayanaswamy, R.; Young, M. A.; Elder, R. C.; Bruce, A. E.; Bruce, M. R. M. Inorg. Chem. 1995, 34, 1996.

(29) Forward, J . M.; Bohmann, D.; Fackler, J . P.; J r., Staples, R. J . Inorg. Chem. 1995, 34, 6330.

CG034198L 